Homes Away from Home 
STANFORD STUDIES IN JEWISH HISTORY AND CULTURE Edited by David Biale and Sarah Abrevaya Stein 


\section{Homes Away from Home}

J E W I S H B E L O N G I G IN

T W E N T I TH - C E N T URY PARIS,

B ERLIN, AN D ST. PETERSBURG

\section{Sarah Wobick-Segev}

STANFORD UNIVERSITY PRESS

S T A N F O R D, C A L I F O R N I A 
Stanford University Press

Stanford, California

(C) 2018 by Sarah E. Wobick-Segev. All rights reserved.

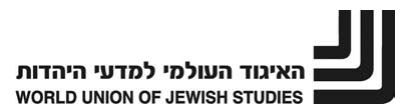

No part of this book may be reproduced or transmitted in any form or by any means, electronic or mechanical, including photocopying and recording, or in any information storage or retrieval system without the prior written permission of Stanford University Press.

Printed in the United States of America on acid-free, archival-quality paper

Library of Congress Cataloging-in-Publication Data

Names: Wobick-Segev, Sarah, author.

Title: Homes away from home : Jewish belonging in twentieth-century Berlin,

Paris, and St. Petersburg / Sarah Wobick-Segev.

Description: Stanford, California : Stanford University Press, 20I8. |

Series: Stanford studies in Jewish history and culture | Includes

bibliographical references and index.

Identifiers: LCCN 2017052515 (print) | LCCN 201705353I (ebook) |

ISBN 9781503605145 (cloth :alk. paper) | ISBN 9781503606548 (ebook)

Subjects: LCSH: Jews-Europe-Social life and customs—2oth century. | Judaism and secularism—Europe-History—2oth century. | Community life-Europe-History—2oth century. | Public spaces-Europe-History2oth century. | Individualism-Europe-History-2oth century. |

Leisure-Europe-History—2oth century.

Classification: LCC DSI35.E83 (ebook) | LCC DSI35.E83 W63 2018 (print) |

DDC $305.892 / 404-\mathrm{dc} 23$

LC record available at https://lccn.loc.gov/2017052515]

Cover design: Angela Moody

Cover painting: Lesser Ury, "Lady in black evening dress with green scarf" (I908).

Wikimedia Commons

Typeset by Bruce Lundquist in II/I4 Adobe Garamond Pro 
To Ran,

For a journey that began many years ago.

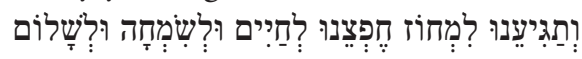

And to our children, Hodaia, Aviad, and Alma

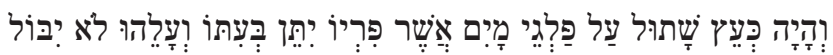

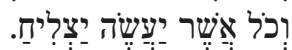

Psalms I:3 
This page intentionally left blank 